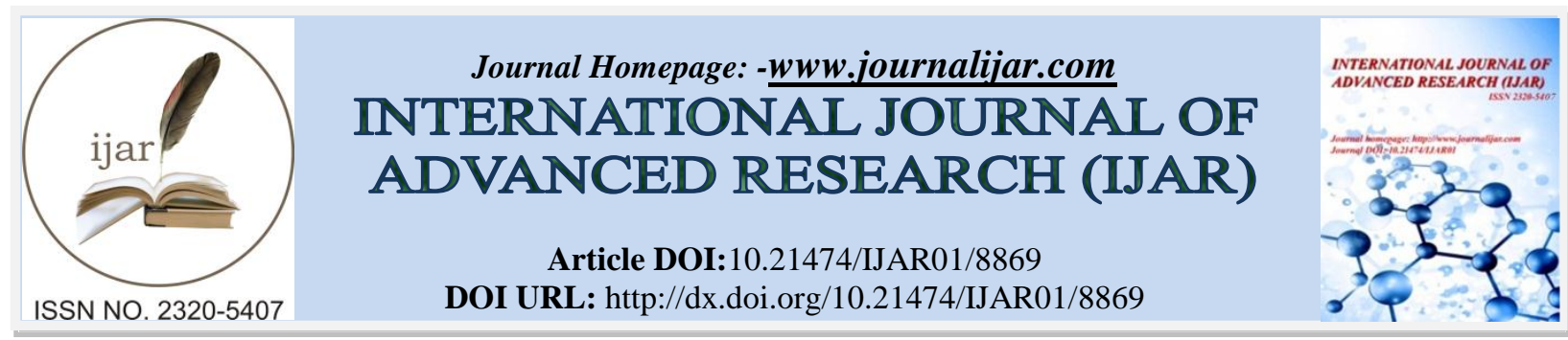

RESEARCH ARTICLE

\title{
ROTALA BAILEYANA SP.NOV. (LYTHRACEAE) FROM KERALA, INDIA.
}

Rogimon P Thomas ${ }^{1}$, Joby Paul ${ }^{2}$, Rameshan M. ${ }^{3}$, Nisha P. ${ }^{4}$ and Ignatius Antony ${ }^{2}$.

1. Department of Botany, CMS College Kottayam (Autonomous), Kerala, India-686001.

2. Department of Botany, St. Thomas' College (Autonomous), Thrissur, Kerala, India.

3. National Centre for Earth Science Studies, Ministry of Earth Sciences, Akkulam,Thiruvananthapuram.

4. Department of Botany, St Xavier's College for Women, Aluva, Kerala, India.

\section{Manuscript Info}

\section{Manuscript History}

Received: 10 February 2019

Final Accepted: 12 March 2019

Published: April 2019

Key words:-

Lateritic temporary pool, Submerged

aquatic, Kasaragod.

\begin{abstract}
Rotala baileyana, a new species of Lythraceae, collected from temporary pools on lateritic hills in Kasaragod district of Kerala, India is described and illustrated. It is similar to R. tulunadensis but differs by its annual habit, oblong-obovate submerged leaves with entire margin; oblong-obovate aerial leaves with retuse apex and clasping base; $2-6 \mathrm{~mm}$ pedicels, absence of bract; triangular-falcate bracteole; presence of nectory gland in the joining of calyx lobes, calyx tube wing with a constriction and projection below the lobes, elliptic-oblong petals with retuse apex; red anther lobes with broad connective.
\end{abstract}

Copy Right, IJAR, 2019,. All rights reserved.

\section{Introduction:-}

The genus Rotala L. (Lythraceae) has more than 55 species and is distributed in tropical and subtropical regions of the world. It shows highest diversity in tropical Asia (Cook, 1979). A total of 31 species are reported so far from India, which includes recently described eleven species from Peninsular India (Yadav et al., 2010; Prasad et al., 2012; Gaikwad et al., 2013; Prasad \& Raveendran 2013a,b; Sunil et al., 2013; Anto et al., 2014; Narayanan et al., 2014; Lemiya \& Pradeep, 2015; Rijuraj et al., 2017 and Lekhak \& Yadav, 2017).

During recent floristic explorations in northern Kerala, we collected an interesting specimen of Rotala, from the lateritic plateau in Kasaragod district which is closely related to $R$. tulunadensis. On critical examination with the type of $R$. tulunadensis, it is revealed that the collected specimen was distinct with taxonomically relevant features. Therefore, the hitherto unknown taxa of the genus is described and illustrated here as a new species.

Rotala baileyana Rogi, Joby, Rameshan, Nisha \& I. Antony sp. nov. (Fig. 1 A - K \& Fig. 2 B - G) Type: India, Kerala, Kasaragod district, Kayyur, Verikken Para Kulam, $12^{\circ} 15^{\prime} 48.71^{\prime \prime} \mathrm{N}, 75^{\circ} 10^{\prime} 53.76^{\prime \prime} \mathrm{E}, 83 \mathrm{~m}$ a.s.l., 10 October 2016, Rogi, Joby \& Rameshan, 601(holotype: CAL, isotypes: MH, CALI, St. Thomas' College (Autonomous) herbarium, Thrissur, Kerala, India, CMS College Kottayam (Autonomous) herbarium,Kottayam,Kerala).

The new species is different from $R$. tulunadensis by having an annual habit, oblong-obovate submerged leaves with entire margin and stem clasping base; oblong-obovate aerial leaves with retuse apex; $2-6 \mathrm{~mm}$ long pedicel, absence of bract; triangular-falcate bracteole; nectary gland in the joining of calyx lobes, calyx tube wing with a constriction and projection below the lobes, petals with retuse apex, red anther lobes with broad connective versus perennial

Corresponding Author:-Rogimon P Thomas.

Address:-Department of Botany, CMS College Kottayam (Autonomous), Kerala, India-686001. 
habit, $1.0-2.3 \times 0.5-1.3 \mathrm{~cm}$ elliptic or ovate submerged leaves with rounded base, obtuse or retuse apex and minutely serrate margins, obovate aerial leaves with rounded apex and base, 1-4 mm long pedicel, leaf like bract, subulate bracteole, absence of nectar gland in calyx tube, calyx tube wing without a constriction and projection below the lobes, petal apex obtuse, connective narrow.

\section{Description}

Aquatic, annual herb, $30 \mathrm{~cm}$ height; Stem cylindrical, minute lines in the internodes Internodes $0.3-1.3 \mathrm{~cm}$, green, slightly reddish, younger branches pinkish red, glabrous, rooting at lower nodes; Leaves dimorphic, decussate. Submerged leaves oblong-obovate $0.4-0.7 \times 1.3-1.8 \mathrm{~cm}$, both surface glabrous, reddish tint in upper surface, reddish violet in lower surface, margin entire, base slightly auricled, clasping the stem, apex retuse, lateral veins 5-7 pairs, obscure. Aerial leaves oblong-ovate, 0.5-0.7 ×0.9-1.2 cm, obovate-orbicular, apex retuse; Flowers axillary, solitary, monomorphic, pedicellate; Pedicel 2-6 mm long, glabrous; Bract absent, Bracteole triangular or falcate, rarely subulate, 8-12 white hairs present inside the bracteole, smooth, green; Calyx tube 4 angled, constricted below the apex, constriction with projection, winged on the angles, enlarging in fruit, $4.5 \times 3 \mathrm{~mm}$, wings tinted purple-red, translucent; lobes 4, triangular, apex acute, red, nectar glands present in the joining of sepals, not as a continuous ring; Petals 4, $1.5 \times 1 \mathrm{~mm}$, elliptic-oblong, rose, margin entire, apex bi-mucronate; Stamens 4, inserted in the middle of calyx tube, episepalous, Filament $1 \mathrm{~mm}$, white, glabrous; Anther lobes red, connective large, broad; Ovary oblong-elliptic, $1.5 \times 0.5 \mathrm{~mm}$, glabrous, quadrangular-winged;Stigma capitate, feathery; Capsule oblong, $3 \times 1.5$ $\mathrm{mm}$, quadrangular-winged, 4 valved, not protruding from the calyx tube; Seeds many, oblong, smooth, minutely striate, green when young, reddish brown when mature.

\section{Etymology}

The new species is named after Rev. Benjamin Bailey, the first principal of CMS College, Kottayam,Kerala and the founder of modern English education in Kerala. He is also deemed to be the progenitor of printing and book publishing in Malayalam language by his establishment of Kerala's first printing press. A nonpareil author and translator, his innumerous contributions to language paved a new legacy in the cultural chronicles of Kerala.

\section{Phenology}

During the rainy season (June-August) the species remains submerged in the permanent and seasonal lateritic pools. During the winter and early summer (September-February), it produces flowers on the emergent aerial branches. Fruiting is observed in November to March.

\section{Habitat and Ecology}

The new species is a short lived annual found in a lateritic lake or depressions on lateritic rocks having a depth of 0.5-1 m. No other species of Rotala was noticed in the entire plateau. The associated flora includes Nymphoides balakrishnanii, Nymphoides indica, Vallisneria spiralis, Marsilea minuta, Wiesneria triandra, Utricularia reticulata etc.

\section{Conservation status}

$R$. baileyana is collected only from the type locality and further exploration on distribution is required for analyzing conservation status and endemism. The ecologically significant seasonal laterite pools and temporary lakes are the major source of groundwater recharge, habitat of several species including migratory birds and having rich biodiversity. The lateritic plateau of Kasaragod district has under severe anthropogenic pressure from extensive mining and unscientific applying of herbicides in the adjoining cashew plantations. Most of the seasonal pools and temporary lakes are reclaimed for industrial and other purpose.

\section{Notes}

R.baileyana is similar to R.tulunadensis and R.sahyadrica (Table -1) but can be distinguished by the following key.

\section{Key to the new species and similar species of Rotala}

1a. Flowers sessile, nectar scales present, nectary glands forms a continuous

1b. Flowers pedicellate, nectar scales absent, nectary gland not a continuous ring............

2a. Perennial, leaf margin minutely serrate, aerial leaves rounded at both ends, bract present, bracteole subulate, nectary glands absent in the joining of sepals tulunadensis 
2b.Annual, leaf margin entire, aerial leaf apex retuse, bract absent, bracteole triangular-falcate, nectory glands in the joining of sepals. baileyana

\section{rbcL gene sequence analysis}

We analyzed the rbcL sequence by using rbcL-PCR universal primers and automated DNA sequencing was performed on ABI3730xl Genetic Analyzer according to Doyle and Doyle (1990). The newly generated sequence has been submitted to GenBank (accession number MK695164).

Additional specimen examined (paratype): India, Kerala, Kasaragod District, Kayyur, Verikken Para Kulam, $12^{\circ} 15^{\prime} 48.71^{\prime \prime} \mathrm{N}, 75^{\circ} 10^{\prime} 53.76^{\prime \prime} \mathrm{E}, 83 \mathrm{~m}$ a.s.1., 12 November 2016, Rogi, Joby \& Rameshan, 614, Herbarium St Thomas'College (Autonomous), Thrissur, Kerala, India.

\section{Acknowledgements:-}

The authors are thankful to the Principal and Head of the Department of Botany,CMS College Kottayam (Autonomous) and St Thomas' College (Autonomous) Thrissur, Kerala for facilities. We are grateful to Ms. Nirmala Ramesh for help during the field work.

Table 1:-Diagnostic characters of $R$. baileyana and similar species

\begin{tabular}{|c|c|c|c|}
\hline Characters & Rotala baileyana & R.tulunadensis & R.sahyadrica \\
\hline Habit & $\begin{array}{l}\text { Aquatic, annual herb, } 30 \mathrm{~cm} \\
\text { height }\end{array}$ & $\begin{array}{l}\text { Aquatic perennial spreading } \\
\text { herb, } 40 \mathrm{~cm} \text { height }\end{array}$ & $\begin{array}{l}\text { Submerged aquatic annual } \\
\text { herb, } 30 \mathrm{~cm} \text { height }\end{array}$ \\
\hline Stem & $\begin{array}{l}\text { Cylindrical, minute lines in the } \\
\text { internodal region, internodes } \\
0.3-1.3 \mathrm{~cm} \text {, green, slightly } \\
\text { reddish, younger branches } \\
\text { pinkish red, glabrous, rooting } \\
\text { at lower nodes }\end{array}$ & $\begin{array}{l}\text { Cylindrical, branched, creeping } \\
\text { and rooting below, floating or } \\
\text { erect above. }\end{array}$ & $\begin{array}{l}\text { Obtusely angular below, } \\
\text { acutely quadrangular above, } \\
\text { erect, rarely branched. }\end{array}$ \\
\hline Leaf & $\begin{array}{l}\text { Dimorphic, decussate, } \\
\text { submerged leaves Oblong- } \\
\text { obovate, } 0.4-0.7 \times 1.3-1.8 \mathrm{~cm}, \\
\text { both surface glabrous, reddish } \\
\text { tint in upper surface, reddish } \\
\text { violet in lower surface, margin } \\
\text { entire, base slightly auricled, } \\
\text { clasping the stem, apex retuse, } \\
\text { lateral veins } 5-7 \text { pairs, obscure. } \\
\text { Aerial leaves: Oblong-ovate, } \\
0.5-0.7 \times 0.9-1.2 \mathrm{~cm}, \text { obovate- } \\
\text { orbicular, apex retuse }\end{array}$ & $\begin{array}{l}\text { Dimorphic, decussate, } \\
\text { submerged leaves } 1.0-2.3 \times 0.5- \\
1.3 \mathrm{~cm} \text {, membranous, elliptic or } \\
\text { ovate, rounded at base, obtuse } \\
\text { or retuse at apex, minutely } \\
\text { serrate at margins; lateral veins } \\
\text { in 5-7 pairs, obscure; Aerial } \\
\text { leaves 5-6×3.0-3.5mm, } \\
\text { obovate, rounded at both ends, } \\
\text { with veins in 5-6 pairs }\end{array}$ & $\begin{array}{l}\text { Opposite, decussate, sessile, } \\
\text { dimorphic, membraneous; } \\
\text { submerged leaves linear- } \\
\text { oblong, rounded at both the } \\
\text { ends, } 4.0-6.5 \times 0.6-1.0 \mathrm{~cm} \text {, } \\
\text { reddish or greenish, entire, with } \\
\text { lateral nerves in } 3-5 \text { pairs, } \\
\text { distinct; aerial leaves obovate } \\
\text { orbicular, cordate at base, } \\
\text { rounded at apex }\end{array}$ \\
\hline Flower & $\begin{array}{l}\text { Axillary, solitary, } \\
\text { monomorphic, pedicellate }\end{array}$ & $\begin{array}{l}\text { Axillary, solitary, } \\
\text { monomorphic, pedicellate }\end{array}$ & Axillary, solitary, sessile \\
\hline Pedicel & 2-6 mm long, glabrous & $1-4 \mathrm{~mm}$ long & Absent \\
\hline Bract & Absent & $\begin{array}{l}\text { Leaf like, decreasing in size } \\
\text { towards apex, obovate, } 2- \\
6 \times 0.5-4.0 \mathrm{~mm} \text {. }\end{array}$ & $\begin{array}{l}\text { Leafy, } 0.5-1.5 \times 0.3-1.0 \mathrm{~cm}, \\
\text { reddish, } \\
\text { entire }\end{array}$ \\
\hline Bracteole & $\begin{array}{l}\text { 1, Triangular -falcate, subulate, } \\
8-12 \text { white hairs present inside } \\
\text { the bracteole, smooth, green }\end{array}$ & Subulate, ca $1 \mathrm{~mm}$ long & $\begin{array}{l}2, \text { linear-subulate, } 0.7-0.9 \mathrm{~mm} \\
\text { long, much shorter than the } \\
\text { calyx tube, persistent, with } 8- \\
12 \text { multicellular, unbranched, } \\
0.2-0.6 \text { mm long, black hairs at } \\
\text { the axils }\end{array}$ \\
\hline Sepal & $\begin{array}{l}\text { Calyx tube } 4 \text { angled, } 4.5 \times 3 \mathrm{~mm} \text {, } \\
\text { constricted below the apex, }\end{array}$ & $\begin{array}{l}\text { Calyx tube } 4 \text { angled, } 2.5-3.0 \\
\text { mm long, constricted below the }\end{array}$ & $\begin{array}{l}\text { Floral tube sub-cylindric to } \\
\text { urceolate, nectar scales present, }\end{array}$ \\
\hline
\end{tabular}




\begin{tabular}{|c|c|c|c|}
\hline & $\begin{array}{l}\text { constriction with minute } \\
\text { projection, winged on the } \\
\text { angles, enlarging in fruit, wings } \\
\text { tinted purple-red, translucent; } \\
\text { lobes } 4 \text {, triangular, apex acute, } \\
\text { red, nectar glands present in the } \\
\text { joining of sepals lobes }\end{array}$ & $\begin{array}{l}\text { apex, with distinct wings on the } \\
\text { angles, accrescent, enlarging in } \\
\text { fruits up to } 4.8 \mathrm{~mm} \text { long; wings } \\
\text { running the whole length of the } \\
\text { tube, } 0.3-0.4 \mathrm{~mm} \text { wide, tinged } \\
\text { red, translucent; lobes } 4, \\
\text { broadly triangular, } 0.8-1.0 \mathrm{~mm} \\
\text { long. }\end{array}$ & $\begin{array}{l}\text { lobes } 4, \text { nectory glands form a } \\
\text { continuous rim on the calyx } \\
\text { tube from where filaments } \\
\text { arise. }\end{array}$ \\
\hline Petal & $\begin{array}{l}4,1.5 \times 1 \mathrm{~mm} \text {, elliptic - oblong, } \\
\text { rose, margin entire, apex } \\
\text { retuse, exerted, pinkish rose }\end{array}$ & $\begin{array}{l}4, \text { ca } 1.2 \times 0.8 \mathrm{~mm} \text {, elliptic to } \\
\text { ovate or suborbicular, exerted, } \\
\text { rose coloured. }\end{array}$ & $\begin{array}{l}4,0.9-1.1 \times 0.8-0.9 \mathrm{~mm}, \\
\text { obovate, obtuse, clawed at } \\
\text { base, rosy-white, opposite to } \\
\text { the calyx lobes }\end{array}$ \\
\hline Stamen & $\begin{array}{l}4, \text { inserted in the middle of } \\
\text { calyx tube, filaments } 1 \mathrm{~mm} \text {, } \\
\text { white, glabrous, Anther lobes } \\
\text { red, connective broad }\end{array}$ & $\begin{array}{l}4 \text {, inserted at about the middle } \\
\text { of calyx- the tube; filaments } \\
0.9-1.0 \mathrm{~mm} \text { long. }\end{array}$ & $\begin{array}{l}4 \text {, inserted below the middle of } \\
\text { calyx tube, included; filaments } \\
\text { narrow towards apex, white }\end{array}$ \\
\hline Carpel & $\begin{array}{l}\text { Oblong-elliptic, } 1.5 \times 0.5 \mathrm{~mm} \text {, } \\
\text { glabrous, quandrangular, } \\
\text { winged; stigma capitate, } \\
\text { feathery. }\end{array}$ & $\begin{array}{l}\text { Ellipsoid, } 1.8-2.0 \mathrm{~mm} \text { long, } 4- \\
\text { angled; style short, ca } 0.5 \mathrm{~mm} \\
\text { long; stigma capitate. }\end{array}$ & $\begin{array}{l}\text { Ellipsoid, } 1.1-1.3 \times 0.9-1.0 \\
\text { mm, yellowish; style simple, } \\
\text { short, persistent in fruit; stigma } \\
\text { capitate, minutely pilose, } \\
\text { included in calyx tube. }\end{array}$ \\
\hline Capsule & $\begin{array}{l}\text { Oblong, } 3 \times 1.5 \mathrm{~mm} \text {, } \\
\text { quadrangular, winged, } 4- \\
\text { valved, not protruding from the } \\
\text { calyx tube. }\end{array}$ & $\begin{array}{l}\text { Ellipsoid, 4-5×2.5-3.0mm, 4- } \\
\text { valved; valves induplicate. }\end{array}$ & $\begin{array}{l}\text { Ellipsoid, } 3.00-3.50 \times 2.00- \\
2.25 \mathrm{~mm} \text {, slightly protruding } \\
\text { from the calyx tube, } 4 \text {-valved; } \\
\text { valves conduplicate, } \\
\text { septicidally dehiscent }\end{array}$ \\
\hline Seed & $\begin{array}{l}\text { Many, } 0.6-0.8 \mathrm{~mm} \text { long, } \\
\text { oblong, smooth, minutely } \\
\text { striate, green when young, } \\
\text { reddish brown when mature. }\end{array}$ & $\begin{array}{l}\text { Many, 0.6-0.7 mm long, } \\
\text { ellipsoid, dark brown. }\end{array}$ & $\begin{array}{l}\text { Ovoid-ellipsoid, } 0.15- \\
0.19 \times 0.20-0.15 \mathrm{~mm} \text {, in } 2-3 \\
\text { rows in each locule, brownish. }\end{array}$ \\
\hline
\end{tabular}

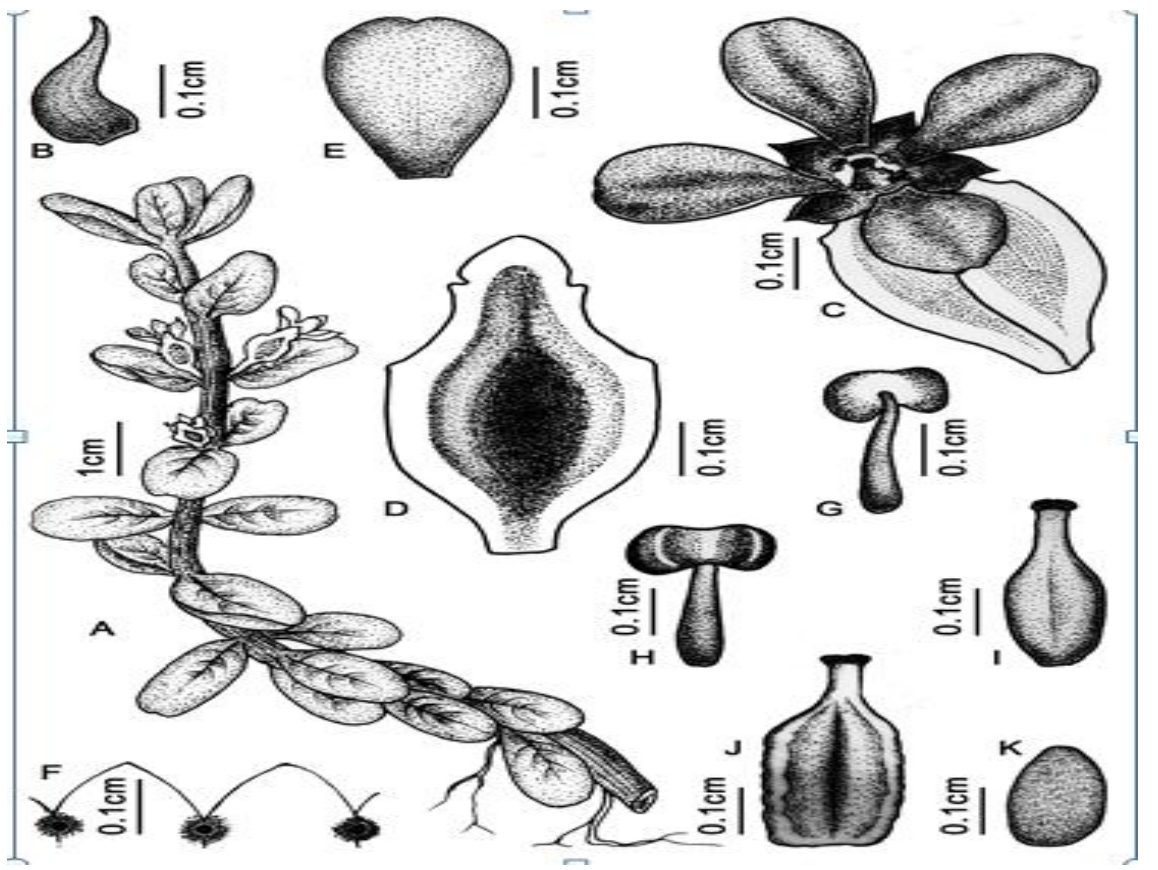

Fig 1:-Rotala baileyana. A. Habit, B. Bracteole, C. Flower, D. Persistent calyx tube, E. Petal, F. Glands in the sepals, G \& H. Stamens, I. Young pistil, J. Mature capsule, K. Seed (All from Rogi,Joby \& Rameshan, 601; drawings by Joby Paul). 

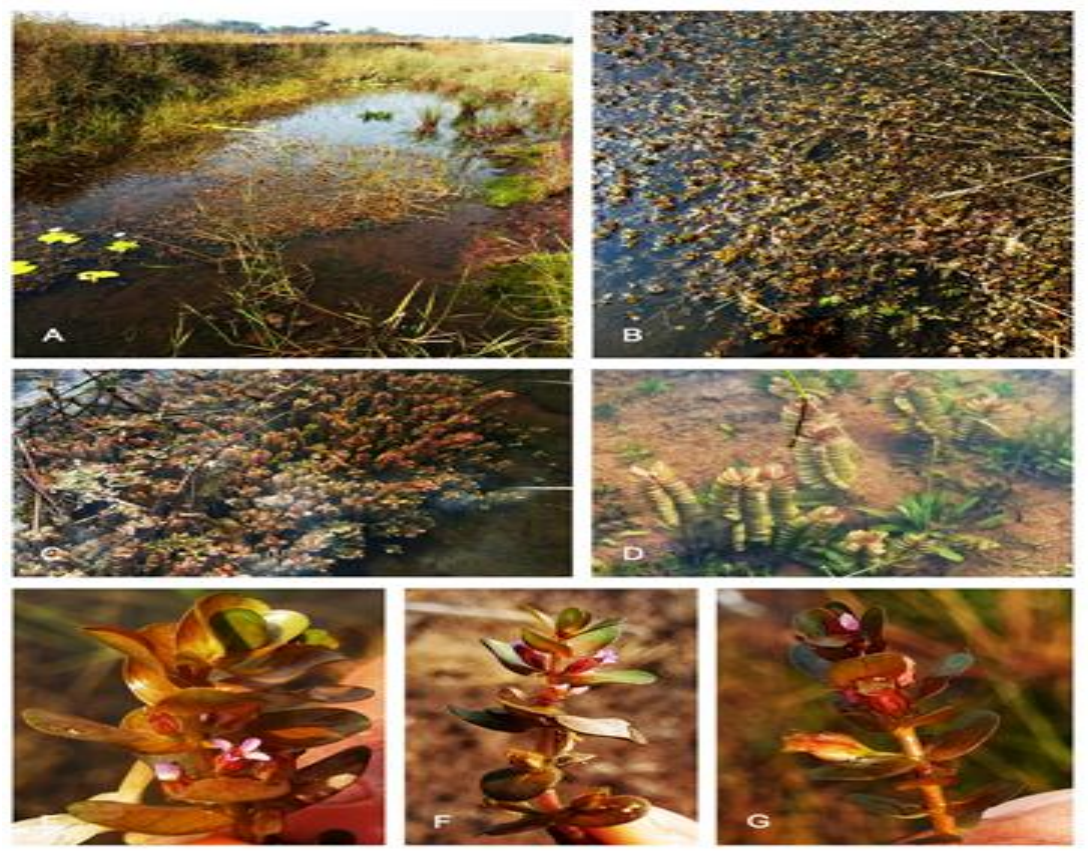

Fig 2:-Rotala baileyana. A. Habitat, B. Mature plants with flowering, C. \& D. Young plants, E., F. \& G. Flowering twigs (Photographs by Rameshan M.).

\section{References:-}

1. Anto, P. V., Devikrishna, C. S., Jacob Abraham, P., Varghese, C. D. \& I. Antony (2014). A new species of Rotala L. (Lythraceae) from the lateritic hills of Thrissur district, Kerala, India. Int. J. Adv. Res. 2(11): 532535.

2. Cook, C. D. K. (1979). A revision of the genus Rotala (Lythraceae). Boissiera 29: 1- 156.

3. Gaikwad, S. P., Sardesai, M. M. \& S. R. Yadav (2013). Rotala sahyadrica sp. nov. (Lythraceae) from western ghats, India. Nordic J. Botany 32(5): 575-577.

4. Lekhak, M. M. \& Yadav, S. R. (2017). Rotala pseudojuniperina, a new species of Lythraceae from India. Nordic Journal of Botany: doi: 10.1111/njb.01518

5. Lemiya K.M. \& A.K. Pradeep (2015). A new species of Rotala (Lythraceae) from Kerala, India. Rheedea 25(2): $159-163$.

6. Narayanan, R. M. K., Sunil, C. N., Shaju, T., Nandakumar, M. K., Sivadasan, M. \& A. H. Alfarhan (2014). Rotala dhaneshiana, a new species of Lythraceae from India. Phytotaxa 188 (4): 227-232.

7. Prasad, K. S. \& K. Raveendran (2013a). A new species of Rotala L. (Lythraceae) from Kerala, India. Taiwania 58 (2): 104-107.

8. Prasad, K. S. \& K. Raveendran (2013b). Rotala kasaragodensis (Lythraceae), a new species from Kerala, India. Edinburgh J. Botany 70 (3):451-454.

9. Prasad, K. S., Biju, P., Raveendran, K. \& K. G. Bhat (2012). Rotala tulunadensis sp. nov. (Lythraceae)from Kerala, India. Nordic J. Botany 30: 59-60.

10. Rijuraj, M. P., M. Rajendraprasad, T. Shaju \& A. G. Pandurangan(2017). The status of the genus Rotala L. (Lythraceae) and description of a new species from Kerala, India. Int. J. Adv. Res. 5(2), 909-914.

11. Sunil, C. N., Ratheesh Narayanan, M. K., Nandakumar, M. K., Jayesh, P. J., Abdul Jaleel, V. \& N. Anil Kumar (2013). Rotala khaleeliana sp.nov. (Lythraceae), a new species from lateritic hills of Kannur, Kerala, India. Int. J. Adv. Res.1(2): 14-16.

12. Yadav, S. R., Malpure, N. V. \& A. N. Chandore (2010). Rotala belgaumensis (Lythraceae) from the western ghats, India. Nordic J. Botany 28:499-500. 